\title{
Isolation of Bacteria with Protease Activity from Cheonggukjang and Purification of Fibrinolytic Enzyme
}

Yeon Hee Choi', Jun Seung Lee', So Young Bae', Keun Jae Yang', Kyu Won Yeom², Dong Hyeok $\mathrm{JO}^{2}$, Ock hwa Kang ${ }^{2}$ and Hyung Suk Baik**

\author{
${ }^{1}$ Department of Microbiology, Pusan National University, Busan 609-735, Korea \\ ${ }^{2}$ Pusan Science High School, Busan 609-310, Korea
}

Received January 9, 2013 /Revised February 12, 2013 /Accepted February 13, 2013

To isolate the fibrinolytic enzyme, 268 strains from 21 samples were morphologically isolated from Cheonggukjang collected from Korea and Japan. Among the 268 strains, protease-producing bacteria were isolated in nutrient agar medium including 1\% skimmed milk. As a result of this, 22 strains were isolated. Apiweb site was used to identify these strains based on their biochemical properties. In addition, 16S rRNA sequencing was performed to identify the strain. Most of the identified strains were Bacillus subtilis and B. amyloliquefaciens. Fibrinolytic enzyme activity was measured with the fibrin plate method. Five strains were finally selected: A2-14, A2-20, C1-05, C1-09, and F2-01. Of those five strains, the A2-20 strain, which is close to B. amyloliquefaciens, showed the strongest fibrinolytic activity. The fibrinolytic enzyme produced by the A2-20 strain was partially purified from culture supernatant by gel filtration and ion exchange chromatography. The optimal $\mathrm{pH}$ and temperature values of the partially purified enzyme were 7.0 and $35^{\circ} \mathrm{C}$, respectively. Purified protein analysis was carried out with SDS-PAGE and zymography. A genetic analysis was also conducted by PCR based on the consensus sequence of fibrinolytic enzyme. Corresponding genes with a partial sequence of the A2-20 strain were identified.

Key words : Bacillus amyloliquefaciens, Cheonggukjang, enzyme purification, fibrinolytic enzyme, protease

\section{서 론}

청국장은 한국의 전통적인 대두 발효 음식으로 단기간에 발효되는 대표적인 식품이다. 볏짚에 사는 고초균인 Bacillus 속을 포함한 많은 미생물들이 발효에 관여하여 청국장과 같은 대두 발효 식품이 만들어지게 되며 이러한 미생물들이 분비하 는 효소들로 인해 청국장 특유의 냄새나 맛이 결정된다[2]. 뿐 만 아니라 청국장은 발효에 관여하는 미생물들에 의해 생산된 여러 생리활성물질들을 포함하고 있으며 이들은 항산화효과 [13], 항암효과[17], 혈압강하효과[5] 등을 가진다고 보고된 바 있다. 미생물이 생산하는 생리활성물질 중에서 protease는 casein 분해능, 혈 전용해능, gelatin 분해능의 특성을 지니고 있 다[11, 14].

최근 서구화된 식습관으로 인해 심장마비나 당뇨와 같은 질병이 늘고 있으며 이와 관련된 사망률 또한 증가하고 있다.

\section{*Corresponding author}

Tel : +82-51-510-2271, Fax : +82-51-514-1778

E-mail : hsubaik@pusan.ac.kr

This is an Open-Access article distributed under the terms of the Creative Commons Attribution Non-Commercial License (http://creativecommons.org/licenses/by-nc/3.0) which permits unrestricted non-commercial use, distribution, and reproduction in any medium, provided the original work is properly cited.
이러한 심·혈관질환의 대표적 원인 중의 하나가 바로 인체 내 에서 비정상적으로 생긴 혈전이다. 혈관에 존재하는 혈전은 정상 혈류를 방해하게 되며 이에 따른 치료책으로써 혈전용해 효소에 대한 관심이 증가하고 있다. 혈전용해효소는 fibrin으 로 구성되는 혈전을 용해할 수 있는 특성을 가진다. 현재 상용 되고 있는 혈전용해효소는 tissue plasminogen activator (t-PA), urokinase, streptokinase, staphylokinase 등이 있으며, 이들 중에서 urokinase만이 경구투여가 가능하다. 하지만 이 러한 혈전용해효소들은 반감기가 짧으며 비용이 비싸다는 단 점을 가지고 있다. 또한 출혈, 알러지 반응 등의 부작용 또한 적지 않다고 알려져 있다[4].

이러한 이유로 값싸고 안전한 혈전용해효소에 관한 연구의 필요성이 대두되고 있으며 전통식품에 존재하는 미생물이 혈 전용해효소를 생산한다는 결과가 보고 된 이후 이에 관한 연 구가 주목 받고 있다 $[3,8]$. 청국장 유래 미생물, 특히 Bacillus속 은 혈전용해효소를 생산하여 외부로 분비하는 주요 균주이며 대표적인 혈전용해효소로는 Bacillus subtilis natto가 생산하는 Nattokinase가 있다. Nattokinase는 serine protease이며 fibrin을 분해하는 특성을 지니고 있다[16]. 혈전용해효소를 생 산하는 균주 중에서도 Bacillus amyloliquefaciens에 속하는 Bacillus amyloliquefaciens CH86-1 [12], Bacillus amyloliquefaciens DC-4 [15], Bacillus amyloliquefaciens DJ-4 [9], Bacillus 
amyloliquefaciens LSSE-62 [18], Bacillus amyloliquefaciens MJ5-41 [7] 등이 보고된 바 있다.

본 연구는 혈전용해효소의 활성이 뛰어난 균주를 확보하고, 생산되는 혈전용해효소의 동정을 위해 청국장에서 혈전용해 활성이 높은 균주를 분리하여 동정하였고 분리된 균주가 생산 하는 혈전용해효소를 부분 정제하는 실험을 수행하였다.

\section{재료 및 방법}

배지

본 실험에서는 Luria-Bertani broth (LB), Brain heart infusion (BHI), Nutrient broth (NB), Tryptic soy broth (TSB) $(\mathrm{BD}, \mathrm{USA})$ 배지를 사용하였으며 모든 배양은 $37^{\circ} \mathrm{C}$ 의 호기성 조건에서 수행하였다.

\section{균주 분리}

청국장에서 균주를 분리하기 위해서 청국장을 $0.9 \% \mathrm{NaCl}$ 용액에 넣고 현탁하였다. 현탁액을 원심분리(13,000 rpm, 10 $\mathrm{min}$ )한 뒤 상등액만을 회수하였고 $0.9 \% \mathrm{NaCl}$ 용액으로 단계 별로 희석하였으며 nutrient agar (NA) 배지에 $100 \mu \mathrm{l}$ 씩 도말 하였다. 도말한 균주는 $37^{\circ} \mathrm{C}$ 에서 16 시간 동안 배양한 뒤 콜로 니의 형태에 따라 분리하였다.

\section{Protease 활성 및 혈전용해 활성 측정}

Protease를 분비하는 균주를 선별하기 위하여 $1 \% \mathrm{skim}$ milk powder가 포함된 NA 배지를 사용하였다. $1 \%$ skim milk powder가 포함된 NA 배지에 균주를 접종하여 $37^{\circ} \mathrm{C}$ 에서 16 시 간 동안 배양한 뒤 콜로니 주위에 생긴 투명환의 크기를 비교 하여 각 균주들의 protease activity를 측정하였다.

혈전용해활성은 Astrup과 Mullertz의 방법[1]을 변형하여 측정하였다. $0.1 \mathrm{M}$ phosphate buffered saline (PBS)에 fibrinogen (Sigma)을 녹여서 제조한 $0.5 \%$ (w/v) fibrinogen solution $5 \mathrm{ml}$ 와 동일 buffer를 이용해 제조한 $1 \%(\mathrm{w} / \mathrm{v})$ agarose solution $20 \mathrm{ml}$ 를 thrombin [100 National Institute of Health $(\mathrm{NIH})$ standard $/ \mathrm{ml}$ ] (Sigma) $100 \mu \mathrm{l}$ 와 함께 섞은 뒤 즉시 petri-dish에 붓고 상온에서 1시간 동안 굳혀 fibrin plate를 제조 하였다. 이 fibrin plate에 지름이 $2 \mathrm{~mm}$ 인 구멍을 똟고 균 상등 액을 원심분리한 시료 $10 \mu 1$ 를 접종한 뒤 $37^{\circ} \mathrm{C}$ 에서 16 시간 동 안 배양하였다. Fibrin plate에 접종한 균주의 주위에 생기는 투명환의 크기를 비교하여 혈전용해활성을 측정하였고 대조 군으로 plasmin (1 U) (Sigma) $10 \mu \mathrm{l}$ 을 시료들과 함께 fibrin plate에 접종하였다. Plasmin은 효소활성 측정 시 10 1,000 $\mathrm{mU}$ 로 농도를 다르게 하여 기준으로 사용하였다.

분리 세균의 형태학적 관찰 및 생리화학적 특성 조사

분리된 세균을 NA 배지에 접종하여 콜로니의 형태를 관찰
하였으며 Gram-staining을 한 뒤 현미경으로 세균의 형태학적 특성을 관찰하였다.

분리세균의 생리학적 특성을 관찰하기 위해 API $20 \mathrm{E} \mathrm{kit}$ (bioMereux)와 API 50 CHB kit (bioMereux)를 사용하였다.

\section{DNA sequencing}

$16 \mathrm{~S}$ rRNA sequencing PCR에서 사용된 template는 $20 \mu \mathrm{l}$ 의 LB broth에 하나의 콜로니를 접종한 뒤 희석하여 준비하 였다. PCR이 되지 않는 균주들은 genomic DNA를 추출한 뒤 template로 사용하였다. Genomic DNA 추출은 Solgent 사의 genomic DNA prep kit를 이용하였다. Primer set는 세균의 genomic DNA에 특이적으로 부착하는 forward primer인 27F (agagtttgatcMtggctcag)와 reverse primer인 1492R (ggYtaccttgttacgactt)를 사용하였다[19]. PCR reaction mixture는 template $1 \mu \mathrm{l}, 2 X$ Taq PCR premix (Solgent) 10 $\mu \mathrm{l}$, forward primer $2 \mu \mathrm{l}(10 \mathrm{pmole} / \mu \mathrm{l})$, reverse primer $2 \mu \mathrm{l}$ (10 pmole/ $\mu \mathrm{l}), \mathrm{dDW} 5 \mu \mathrm{l}$ 를 섞은 뒤 PCR을 수행하였다.

$\mathrm{PCR}$ cycle은 $94^{\circ} \mathrm{C}$ 에서 $10 \mathrm{sec}, 45^{\circ} \mathrm{C}$ 에서 $20 \mathrm{sec}, 72^{\circ} \mathrm{C}$ 에서 $1 \mathrm{~min}$ 수행하였다. PCR 과정은 30 번 반복하였다. Pre-denaturation과정은 $94^{\circ} \mathrm{C}$ 에서 $2 \mathrm{~min}$ 간 수행하였고 post-elongation 과정은 $72^{\circ} \mathrm{C}$ 에서 $5 \mathrm{~min}$ 수행하였다. $\mathrm{PCR}$ 의 결과는 $0.8 \%$ agarose gel에서 확인하였다

PCR product를 정제하기 위해 QIAquick ${ }^{\circledR}$ Gel Extraction kit를 사용하였다. 균주 동정을 위해 정제된 DNA를 sequencing한 뒤 BLAST (Basic Local Alignment Search Tool)를 이용 해 분석하였다.

혈전용해효소의 부분적인 염기서열을 증폭하기 위해 forward primer로 p572 (cagacaatgagYRcVatgag), reverse primer로 p573 (gtccaRKtcgggtgcttag)를 사용하였다.

\section{혈전용해효소의 정제}

균주를 TSB배지에서 키운 다음 원심분리(8,000 rpm, 30 $\mathrm{min}$ )를 하여 상등액만을 회수하였다. 상등액에 ammonium sulfate $(80 \%$ saturation, $\mathrm{w} / \mathrm{v})$ 를 가한 뒤 원심분리 $(8,000 \mathrm{rpm}$, $30 \mathrm{~min}$ )를 하였고 pellet만을 모아 $20 \mathrm{mM}$ Tris- $\mathrm{HCl}$ buffer $(\mathrm{pH}$ 7.0) $10 \mathrm{ml}$ 에 녹인 후 24시간 동안 동일 buffer로 3회 교환하며 투석하였다. 투석한 효소액은 활성 측정 후 동결건조로 농축 하였다. 효소정제를 위한 크로마토그래피는 FPLC를 이용하 여 수행하였다. 투석한 효소액을 $20 \mathrm{mM}$ Tris- $\mathrm{HCl}$ buffer $(\mathrm{pH}$ 7.0)로 평형화한 HiLoad 16/60 Superdex 200 prep grade column $(60 \mathrm{~cm} \times 1.6 \mathrm{~cm}$ ) (Amersham)에 flow rate $1 \mathrm{ml} / \mathrm{min}$ 로 분획하였다. Gel filtration으로 받은 단백질 fraction중 활성 을 나타내는 분획을 모아서 amicon YM-10 (Millipore, USA) 을 이용하여 농축한 후 이 효소액을 $20 \mathrm{mM}$ Tris- $\mathrm{HCl}$ buffer $(\mathrm{pH} 7.0)$ 로 평형화한 HiTrap Q HP $1 \mathrm{ml}$ column $(1.6 \mathrm{~cm} x$ $2.5 \mathrm{~cm}$ ) (Amersham)에 flow rate $1 \mathrm{ml} / \mathrm{min}$ 로 흡착시켰다. 2 
$\mathrm{N} \mathrm{NaCl}$ 이 포함된 $20 \mathrm{mM}$ Tris- $\mathrm{HCl}$ buffer (pH 7.0)로 linear gradient 법을 이용하여 column에 흡착된 단백질을 용출시킨 후 활성을 가지는 단백질 fraction을 모아 amicon YM-10 devices (Millipore, USA)을 이용하여 농축하였다.

\section{혈전용해효소의 성질 조사}

$\mathrm{pH}$ 가 효소에 미치는 영향을 알아보기 위해 부분 정제된 효소를 $0.1 \mathrm{M}$ citrate- $\mathrm{NaOH}$ buffer (pH 3.0 to 5.0), sodium phosphate buffer ( $\mathrm{pH} 6.0$ to 7.0), Tris- $\mathrm{HCl}$ buffer ( $\mathrm{pH} 8.0$ to 9.0 )와 각각 섞은 후 $37^{\circ} \mathrm{C}$ 에서 2 시간 동안 반응시켰다. 반응 후에 남은 효소의 활성을 측정하기 위하여 fibrin plate test를 수행하였다. 효소의 열 안정성을 측정하기 위하여 부분 정제 된 효소와 sodium phosphate buffer ( $\mathrm{pH}$ 7.0)를 섞은 후 30 60 ${ }^{\circ} \mathrm{C}$ 에서 30 분 동안 반응시켰고, 반응 후에 남은 효소의 활성은 fibrin plate test로 측정하였다.

\section{부분 정제 단백질 확인}

부분정제 단백질 확인에는 SDS-PAGE와 fibrin zymography [10]를 사용하였다. SDS-PAGE는 12\% acrylamide gel 을 사용하여 전기영동을 수행하였다. 전기영동이 끝난 SDSPAGE gel은 Coomassie Brilliant Blue (CBB) R-250으로 염색 하였다. Fibrin zymography는 $0.12 \%(w / v)$ fibrinogen과 thrombin $(50 \mathrm{NIH} / \mathrm{ml}) 100 \mu 1$ 를 포함한 $12 \%$ acrylamide gel 을 사용하여 전기영동을 수행하였다. 전기영동이 끝난 zymography gel은 $2.5 \%$ Triton X-100이 포함된 $50 \mathrm{mM} \mathrm{Tris-HCl}$ $(\mathrm{pH}$ 7.4)에 담가 상온에서 $30 \mathrm{~min}$ 동안 반응시켰다. Zymography gel에서 Triton X-100 성분을 씻어내기 위해
$\mathrm{dDW}$ 로 wash한 뒤 $50 \mathrm{mM}$ Tris- $\mathrm{HCl}\left(\mathrm{pH}\right.$ 7.4)에 담가 $37^{\circ} \mathrm{C}$ 조건에서 12 시간 동안 반응시켰다. 반응이 끝난 zymography gel은 CBB R-250으로 염색 한 뒤 결과를 관찰하였다.

\section{결과 및 고찰}

\section{청국장 균주 선별}

부산 지역 재래시장 및 대구 지역 재래시장, 일본 등지에서 수집한 21 개의 청국장 시료를 $0.9 \% \mathrm{NaCl}$ 용액에 현탁 하여 NA 배지에서 배양한 뒤 형태가 다른 콜로니를 선별하여 268 여 종의 균주를 1 차 분리하였다(Fig. 1A). 콜로니 형태는 크게 9가지로 분류할 수 있었고, 크기가 크며 밝은 베이지색을 띠고 마른 표면을 가진 콜로니가 다수를 차지하였다. 노란빛을 띠 며 상대적으로 크기가 작고 광택을 띠는 콜로니도 적게나마 관찰되었다.

Protease 활성을 측정하기 위하여 $1 \% \mathrm{skim}$ milk가 포함된 $\mathrm{NA}$ 배지상에서 콜로니 주위에 생기는 투명환의 크기를 비교 하였고(Fig. 1B), 그 결과 protease 활성이 우수한 22여 종의 균주를 분리하였다. Gram-staining을 통한 현미경 관찰 결과 22 개의 균주 모두 그람 양성의 간균이었다.

우수한 혈전용해능을 가지는 균주를 분리하기 위하여 LB 배지에서 16시간 배양한 균상등액 $10 \mu 1$ 를 시료로 이용하였고 대조군으로 plasmin $1 \mathrm{U}$ 를 이용하여 fibrin배지에서 투명환의 크기를 측정하였다(Fig. 2A). 우선적으로 혈전용해활성을 가 지는 균주를 분리하였으며 이들 균주를 fibrin배지에 접종하여 각각 12 시간, 16 시간 동안 배양한 뒤 각 배양시간 별로 접종원 주위에 생긴 투명환의 지름을 측정하여 최종적으로 균주를
A
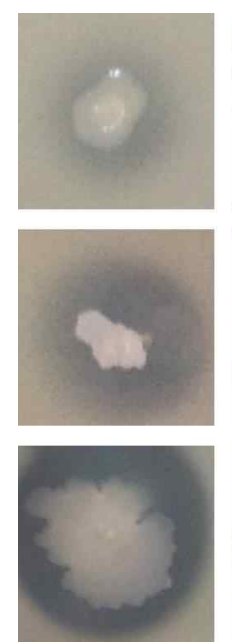
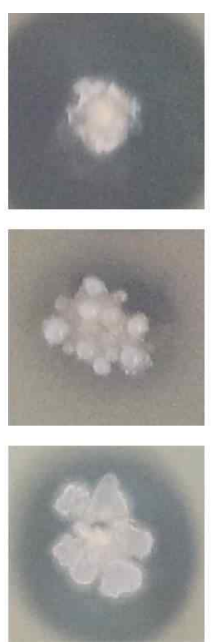
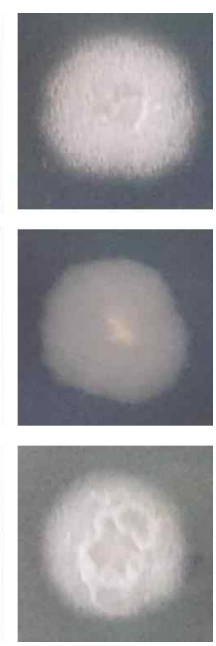

B

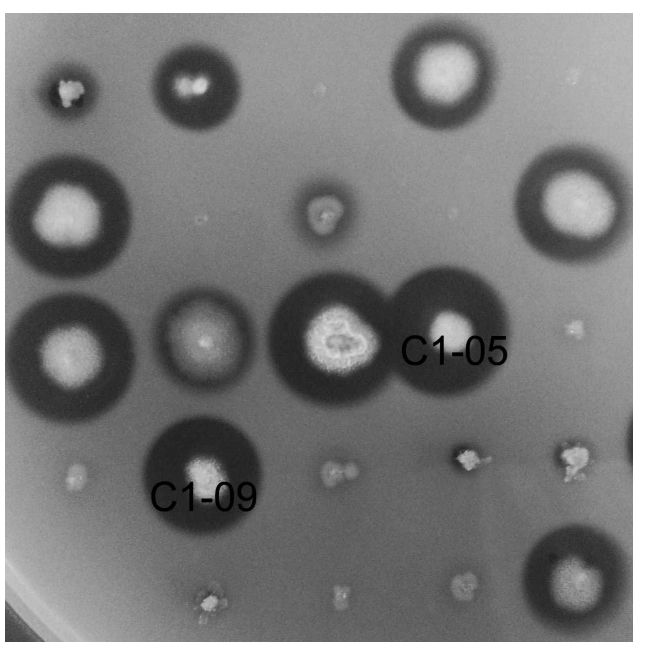

Fig. 1. Isolation of protease-producing bacteria. (A) Colony shape of bacteria isolated from Cheonggukjang. There were nine basic shapes of bacteria based on the single colony. 268 strains from 21 samples were morphologically isolated. (B) Protease activity test of strains on nutrient agar added $1 \%$ skim milk. Bacteria was incubated for $16 \mathrm{hr}$ at $37^{\circ} \mathrm{C}$. The protease-producing strain was selected by measuring clear zone on a culture plate. Protease producing bacteria was isolated in $1 \%$ skim milk agar plates. As a result of this, 22 strains were isolated. 
A

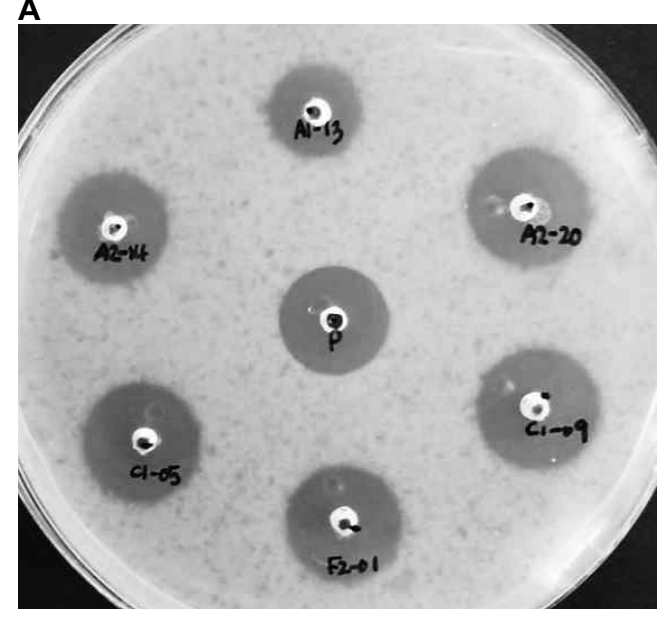

B

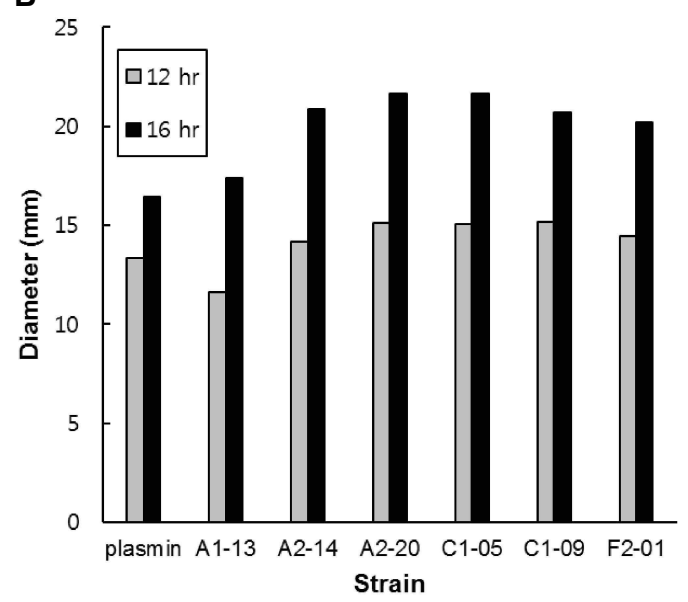

Fig. 2. Comparison of fibrinolytic activity shown by bacteria isolated from Cheonggukjang. (A) Fibrin plate test. The fibrinolytic enzyme producing strain was selected by measuring clear zone in fibrin plate. P: plasmin $1 \mathrm{U}$ (control). (B) Diameter of the clear zone by fibrinolytic activity of each strain. A2-20 strain showed highest fibrinolytic activity. plasmin: control, used $1 \mathrm{U}$.

선별하였다(Fig. 2B). 상대적으로 fibrin 분해능이 뛰어난 균주 는 A2-14, A2-20, C1-05, C1-09, F2-01이었으며, 이들은 비슷한 활성을 나타내었다. 이중에서 혈전용해능이 뛰어난 A2-20 균 주를 최종적으로 선택하여 추후 혈전용해효소 분리 및 동정 실험을 진행하였다.

\section{분리된 균주 동정}

Protease 및 혈전용해효소를 생산하는 22개의 균주를 동정하 기 위하여 $16 \mathrm{~S}$ rRNA sequence를 분석하였고 BLAST를 수행하 였다. 또한 API $20 \mathrm{E}$ kit 및 API $50 \mathrm{CH}$ kit로 carbohydrate 발효 능을 측정하였고 apiweb (https://apiweb.biomerieux.com/)에 서 균주 동정을 실시하였다(Table 1). Protease 활성이 높은 균주들은 대부분 Bacillus amyldiquefaciens와 Bacillus subtilis로 동정되었고, 그 중에서도 fibrin 분해능이 뛰어난 $\mathrm{A} 2-14$, A2-20, C1-05, C1-09, F2-01의 5개 균주 모두 Bacillus amyloliquefaciens와 $99 \%$ 의 유전자 상동성을 보였다. 이를 근거로 본 실험에 사용된 균주를 Bacillus amyloliquefaciens A2-20으로 명 명하였다.

\section{균주 생장에 따른 혈전용해활성}

A2-20 균주를 4 개의 서로 다른 배지에 $1 \%$ 로 접종한 뒤 40 시 간 동안 배양하면서 생장과 혈전용해활성을 측정하였다(Fig. 3). A2-20 균주는 4 개의 배지 중 $\mathrm{NB}$ 에서는 8 시간 이후에는 거의 생장하지 못하였다. TSB와 LB배지에서는 16 시간 일 때, $\mathrm{BHI}$ 배지에서는 18 시간일 때 정지기에 들어섰다. TSB, $\mathrm{LB}$, $\mathrm{BHI}$ 배지에서는 28시간 이후 생장이 서서히 감소하였다(Fig. $3 \mathrm{~A}$ ). TSB배지상에서 가장 높은 혈전용해활성이 나타났으며, 배양 14 시간 후에 $992 \mathrm{mU} / \mathrm{ml}$ 로 최대 활성을 나타내었다. 16
시간 이후부터는 활성이 급격하게 떨어졌고 20시간 이후로는 4 개의 배지 중에서 효소활성이 가장 낮았다. LB배지에서는 10 시간 배양 시 $897 \mathrm{mU} / \mathrm{ml}$ 로 최대 효소활성을 나타내었고 그 뒤 활성이 조금씩 감소하였다. BHI배지에서는 18 시간 배양 시 $873 \mathrm{mU} / \mathrm{ml}$ 로 최대 효소활성을 나타내었고 활성이 유지되 다가 32시간 이후부터 감소하였다. $\mathrm{NB}$ 에서는 20 시간 배양 시 $668 \mathrm{mU} / \mathrm{ml}$ 로 최대효소활성을 가졌지만 다른 배지와 비교하 였을 때 전반적으로 낮은 효소활성을 나타내었다(Fig. 3B). 이 결과로 A2-20 균주의 생장과 혈전용해활성은 배양 배지에 의 해 영향을 많이 받으며 TSB 배지에서 효소활성이 최대가 됨을 확인하였다.

\section{$\mathrm{pH}$ 와 온도가 혈전용해효소활성에 미치는 영향}

$\mathrm{pH}$ 가 효소에 미치는 영향을 알아보기 위하여 부분 정제된 효소를 서로 다른 $\mathrm{pH}$ 를 가지는 buffer와 섞어 $37^{\circ} \mathrm{C}$ 에서 2 시간 동안 반응시킨 뒤 fibrin plate test로 실활 되지 않고 남은 활성 을 측정하였다(Fig. $4 \mathrm{~A}$ ). 효소는 $\mathrm{pH}$ 7.0에서 잔존 활성이 가장 뛰어났고, $\mathrm{pH} 5.0 \sim 9.0$ 의 범위에서는 $90 \%$ 이상의 활성을 보이 며 높은 안정성을 나타냈다. 하지만 낮은 $\mathrm{pH}$ 조건에서는 효소 의 활성이 저하됨을 확인할 수 있었다.

온도가 효소활성에 미치는 영향을 알아보기 위하여 효소를 sodium phosphate buffer ( $\mathrm{pH}$ 7.0)와 섞은 후 $30 \sim 60^{\circ} \mathrm{C}$ 에서 30 분 동안 반응시키고 fibrin plate test로 결과를 확인하였다 (Fig. 4B). 효소는 $30 ~ 35^{\circ} \mathrm{C}$ 에서 열 안정성이 가장 높았고 $35 \sim 4$ $0^{\circ} \mathrm{C}$ 범위에서는 $92 \%$ 이상의 활성이 나타났다. 하지만 $50^{\circ} \mathrm{C}$ 에 서 30 분간 열처리 시 잔존 활성이 $82 \%$ 로 낮아졌으며 그보다 더 높은 온도로 열처리를 한 경우 잔존 활성이 급격하게 낮아 지는 것을 관찰 할 수 있었다. 
Table 1. Carbohydrate fermentation by fibrinolytic enzyme producing-strain as assessed in API 50CH kit

\begin{tabular}{|c|c|c|c|c|c|}
\hline \multirow{2}{*}{ Carbohydrate } & \multicolumn{5}{|c|}{ Strain No. } \\
\hline & $\mathrm{A} 2-14$ & A2-20 & C1-05 & C1-09 & F2-01 \\
\hline Control (Temoin) & - & - & - & - & - \\
\hline Glycerol & + & + & + & + & + \\
\hline Erythritol & - & - & - & - & - \\
\hline D-Arabinose & - & - & - & - & - \\
\hline L-Arabinose & + & + & + & + & ++ \\
\hline D-Ribose & + & + & + & + & ++ \\
\hline D-Xylose & + & + & + & + & + \\
\hline L-Xylose & - & - & - & - & - \\
\hline D-Adonitol & - & - & - & - & - \\
\hline Methyl-ß3-D-xylopyranoside & - & - & - & - & - \\
\hline D-Galactose & + & + & - & - & + \\
\hline D-Glucose & ++ & ++ & + & ++ & ++ \\
\hline D-Fructose & ++ & ++ & + & ++ & ++ \\
\hline D-Mannose & ++ & ++ & + & ++ & ++ \\
\hline L-Sorbose & - & - & - & - & - \\
\hline L-Rhamnose & - & - & - & - & - \\
\hline Dulcitol & - & - & - & - & - \\
\hline Inositol & + & + & - & - & + \\
\hline D-Mannitol & + & ++ & + & + & ++ \\
\hline D-Sorbitol & + & ++ & + & + & ++ \\
\hline Methyl-a-D-mannopyranoside & - & - & - & - & - \\
\hline Methyl-a-D-glucopyranoside & + & ++ & + & + & + \\
\hline N-Acetylglucosamine & - & ++ & + & + & + \\
\hline Amygdlin & - & - & + & + & - \\
\hline Arbutin & - & - & - & - & - \\
\hline Esculin & + & - & + & + & - \\
\hline Salicin & + & - & ++ & + & + \\
\hline D-Cellobiose & ++ & ++ & ++ & + & ++ \\
\hline D-Maltose & ++ & + & ++ & + & + \\
\hline D-Lactose (bovine origin) & + & + & ++ & + & ++ \\
\hline D-Melibiose & + & + & - & - & + \\
\hline D-Saccharose (sucrose) & ++ & ++ & ++ & + & ++ \\
\hline D-Trehalose & + & + & - & - & + \\
\hline Insulin & - & - & + & - & - \\
\hline D-Melezitose & - & - & - & - & - \\
\hline D-Raffinose & + & + & + & + & + \\
\hline Amidon (starch) & ++ & - & + & + & - \\
\hline Glycogen & ++ & - & + & + & - \\
\hline Xylitol & - & - & - & - & - \\
\hline Gentiobiose & + & - & + & + & - \\
\hline D-Turanose & - & - & - & - & - \\
\hline D-Lyxose & - & - & - & - & - \\
\hline D-Tagatose & - & - & - & - & - \\
\hline D-Fucose & - & - & - & - & - \\
\hline L-Fucose & - & - & - & - & - \\
\hline D-Arabitol & - & - & - & - & - \\
\hline L-Arabitol & - & - & - & - & - \\
\hline Potassium gluconate & - & - & - & - & - \\
\hline Potassium 2-ketoGluconate & - & - & - & - & - \\
\hline Potassium 5-ketoGluconate & - & - & - & - & - \\
\hline
\end{tabular}

++: strong positive, + : positive, -: negative 

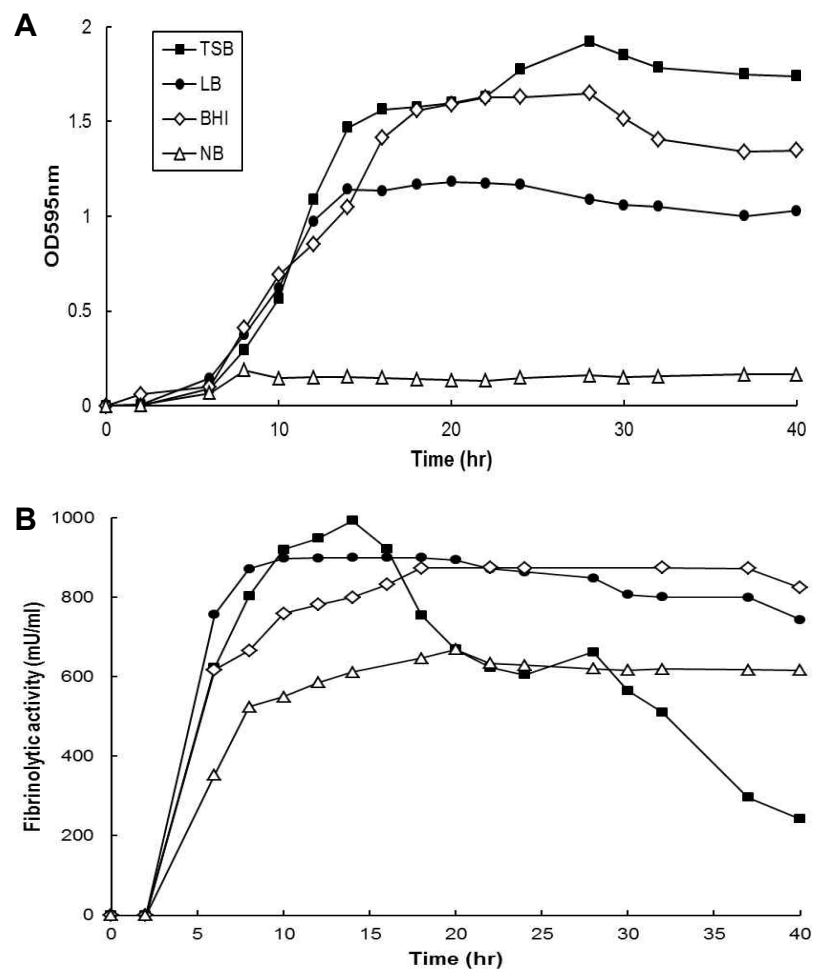

Fig. 3. Growth curve (A) and fibrinolytic activity (B) by culture time of A2-20 strain on different media.

$\diamond$ : BHI, $\triangle$ : NB. Culture supernatant $10 \mu \mathrm{l}$ was incubated on fibrin plate for $16 \mathrm{hr}$ at $37^{\circ} \mathrm{C}$.

\section{부분정제 및 단백질 분석}

A2-20 균주가 생산하는 혈전용해효소는 크로마토그래피를 사용하여 정제하였다. HiLoad 16/60 Superdex 200 prep grade column과 HiTrap Q HP $1 \mathrm{ml}$ column을 사용하여 flow rate $1.0 \mathrm{ml} / \mathrm{min}$ 로 FPLC를 수행하였고, SDS-PAGE 및 fibrin zymography로 분리된 단백질을 분석하였다(Fig. 5). 크로마토 그래피 수행 결과 약 $14 \mathrm{kDa}, 16 \mathrm{kDa}, 18 \mathrm{kDa}, 24 \mathrm{kDa}, 38$ $\mathrm{kDa} 5$ 가지 size의 단백질이 농축되었음을 확인하였다(Fig. $5 \mathrm{~A}$, Lane 3). Fibrin zymography의 결과 ammonium sulfate 염석 후 투석한 시료(Fig. 5B, Lane 1)와 gel filtration을 수행한 시료(Fig. 5B, Lane 2)에서는 4 개의 band가 확인되었다. Ion exchange chromatography에서 분리된 단백질의 경우 zymography 상에서 거의 내려가지 않았음을 관찰 할 수 있었다 (Fig. 5B, Lane 3). 이는 gel상에서 기질인 fibrin과 혈전용해효 소가 강하게 결합하거나 효소의 $\mathrm{pI}$ 값이 높을 때 나타나는 현상 이다[7]. 이에 따라 A2-20 균주는 주요한 혈전용해효소와 부가 적인 혈 전용해효소를 생산하며 주요 효소는 강한 fibrin 결합 력을 지니는 것으로 판단된다.

또한 염기서열에 따른 혈전용해효소 분석을 위해 $\mathrm{NCBI}$ Genbank에서 무작위적으로 선택한 혈전용해효소의 염기서 열을 분석하여 공통된 염기서열을 토대로 primer를 디자인하 였다. Primer 디자인에 참고한 염기서열의 accession number

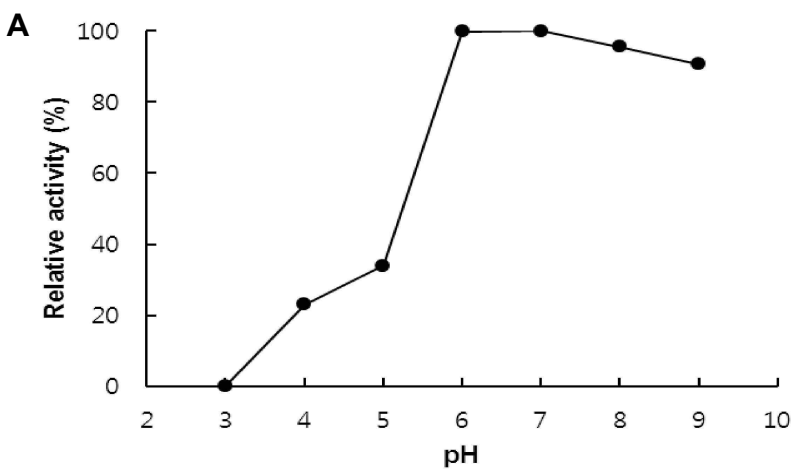

B

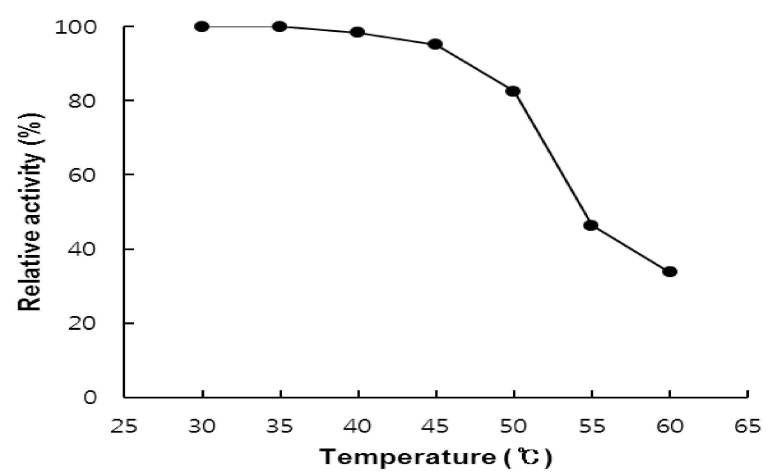

Fig. 4. Effects of $\mathrm{pH}(\mathrm{A})$ and temperature (B) on the activity of partially purified fibrinolytic enzyme. (A) The optimal $\mathrm{pH}$ was determined by incubating the enzyme at $37^{\circ} \mathrm{C}$ with different buffers: $0.1 \mathrm{M}$ citrate buffer ( $\mathrm{pH} 3.0-5.0$ ), sodium phosphate buffer ( $\mathrm{pH}$ 6.0-7.0), Tris- $\mathrm{HCl}$ buffer ( $\mathrm{pH}$ 8.0-9.0). (B) The optimal temperature was measured at various temperatures of $30-60^{\circ} \mathrm{C}$.

는 HQ699519.1, CP002183.1, AJ539133.1, FJ517584.1, CP002905.1, CP002468.1, HE717022.1, Q997813.1, DQ997812.1, AJ579472.2, AL009126.3, EF533986.1, AY940167.1, AY940162.1, JN392072.1, FJ374767.1, EF474344.1, EU734749.1, FJ556884.1, JQ927217.1, FJ517583.1, JF739176.1, FJ882063.1, HQ419279.1 로 총 24가지였다. 앞서 서술된 p572, p573 primer로 PCR한 결과 $0.9 \mathrm{~kb}$ 의 DNA fragment가 증폭되었고 이를 sequencing 하였다. BLAST를 통한 염기서열 분석결과 A2-20 균주의 혈전 용해효소를 암호화하는 DNA 염기서열과 Bacillus amyloliquefaciens LSSE-62 및 Bacillus sp. DJ-4의 혈전용해효소 를 암호화하는 DNA 염기서열이 부분적으로 유전적 상동성을 지니는 것으로 확인되었다(Table 2). A2-20 균주는 Bacillus amyloliquefaciens LSSE-62의 혈전용해효소 염기서열과 1149 $\mathrm{bp}$ 중에서 $852 \mathrm{bp}(74 \%)$ 가 일치하였고 Bacillus sp. DJ-4의 혈전 용해효소 염기서열과는 $1146 \mathrm{bp}$ 중에서 $850 \mathrm{bp}(74 \%)$ 가 일치 하였다. 또한 Conserved Domain Database (CDD) 검색결과 Peptidases S8 Subtilisin subset (CDD number: cd07477)에 해 당하는 conserved domain이 존재함을 확인하였다. 이 domain은 subtilisin 단백질의 peptidase S8 family domain로 
Table 2. Corresponding genes with partial fibrinolytic enzyme sequence of A2-20 strain

\begin{tabular}{lccccc}
\hline \multicolumn{1}{c}{ Identified gene } & Accession No. & Length & \multicolumn{2}{c}{ correspond range } & Identities \\
\hline $\begin{array}{l}\text { Bacillus amyloliquefaciens } \text { strain LSSE-62 fibrinolytic } \\
\text { enzyme gene, complete cds }\end{array}$ & HQ419279.1 & $1149 \mathrm{bp}$ & $167 \mathrm{nt}-1019 \mathrm{nt}$ & $852 / 852(100 \%)$ \\
$\begin{array}{l}\text { Bacillus sp. DJ-4 pro-subtilisin DJ-4 gene, partial cds } \\
\text { HY }\end{array}$ & AY627764.1 & $1146 \mathrm{bp}$ & $169 \mathrm{nt}-1019 \mathrm{nt}$ & $850 / 850(100 \%)$ \\
\hline
\end{tabular}

A

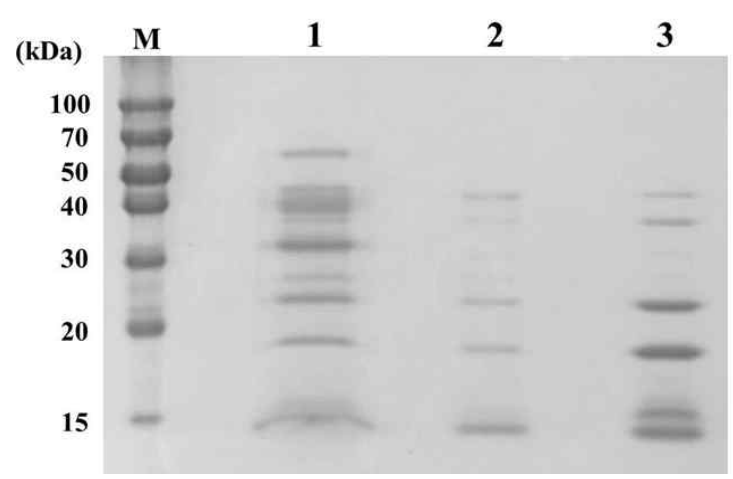

B

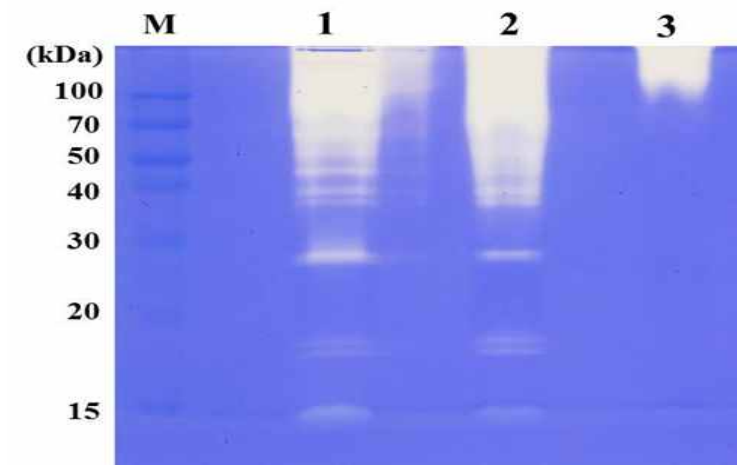

Fig. 5. SDS-PAGE (A) and zymography of fibrinolytic enzyme (B) from A2-20 strain. Lane M, protein marker; Lane 1, after ammonium sulfate precipitation; Lane 2, the active fraction from a HiLoad 16/60 Superdex 200 pg column; Lane 3, the active fraction from a HiTrap Q HP column.

서 다양한 subtilisin 단백질이 여기에 포함된다. Subtilisin에 속하는 단백질이 주요 혈전용해효소라는 연구 결과를 토대로 [6] A2-20 균주가 생산하는 혈전용해효소 중 주요 혈전용해효 소는 subtilisin-type protease라는 것을 알 수 있었다.

\section{감사의 글}

이 논문은 부산대학교 자유과제 학술연구비(2년)에 의하여 연구되었음.

\section{References}

1. Astrup, T. and Mullertz, S. 1952. The fibrin plate method for estimating fibrinolytic activity. Arch Biochem Biophys 40, 346-351.
2. Back, L. M., Park, L. Y., Park, K. S. and Lee, S. H. 2008. Effect of starter cultures on the fermentative characteristics of cheonggukjang. Korean J Food Sci Technol 40, 400-405.

3. Baek, H., Lim, H. S., Chung, K. T., Choi, Y. H., Choi, B. T., Seo, M. J., Kim, J. E., Ryu, E. J., Huh, M. K., Joo, W. H. and Jeong, Y. K. 2005. Characterization of a novel fibrinolytic enzyme produced from Bacillus subtilis BK-17. J Life Sci 15, 987-993.

4. Baruah, D. B., Dash, R. N., Chaudhari, M. R. and Kadam, S. S. 2006. Plasminogen activators: A comparison. Vascul Pharmacol 44, 1-9.

5. Cho, Y. J., Cha, W. S., Bok, S. K., Kim, M. U., Chun, S. S. and Choi, U. K. 2000. Production and separation of anti-hypertensive peptide during chunggugjang fermentation with Bacillus subtilis CH-1023. J Korean Soc Agric Chem Biotechnol 43, 247-252.

6. Choi, N. S., Chung, D. M., Ryu, C. R., Yoon, K. S., Maeng, P. J. and Kim, S. H. 2006. Identification of three extracellular proteases from Bacillus subtilis KCTC 3014. I Microbiol Biotechnol 16, 457-464.

7. Jo, H. D., Lee, H. A., Jeong, S. J. and Kim, J. H. 2011. Purification and characterization of a major fibrinolytic enzyme from Bacillus amyloliquefaciens MJ5-41 isolated from Meju. J Microbiol Biotechnol 21, 1166-1173.

8. Kim, I. J., Kim, H. K., Chung, J. H., Jeong, Y. K. and Ryu, C. H. 2002. Study of functional chungkukjang contain fibrinolytic enzyme. J Life Sci 12, 357-362.

9. Kim, S. H. and Choi, N. S. 2000. Purification and characterization of subtilisin DJ-4 secreted by Bacillus sp. strain DJ-4 screened from Doen-Jang. Biosci Biotechnol Biochem 64, 1722-1725.

10. Kim, S. H., Choi, N. S. and Lee, W. Y. 1998. Fibrin Zymography: A direct analysis of fibrinolytic enzymes on gels. Anal Biochem 263, 305-600.

11. Kim, W. K., Choi, K. H., Kim, Y. T., Park, H. H., Choi, J. Y., Lee, Y. S., Oh, H. I., Kwon, I. B. and Lee, S. Y. 1996. Purification and characterization of a fibrinolytic enzyme produced from Bacillus sp. strain CK 11-4 screened from chungkook-Jang. Appl Environ Microbiol 62, 2482-2488.

12. Kwon, G. H., Lee, H. A., Park, J. Y., Kim, J. S., Lim, J., Park, C. S., Kwon, D. Y., Kim, Y. S. and Kim, J. H. 2009. Development of a RAPD-PCR method for identification of Bacillus species isolated from cheonggukjang. Int $J$ Food Microbiol 29, 282-287.

13. Lee, J. J., Cho, C. H., Kim, J. Y., Kee, D. S. and Kim, H. B. 2001. Antioxidant activity of substances extracted by alcohol from chungkukjang powder. Korean J Microbiol 37, 177-181.

14. Oh, J. H., Lee, B. J., Paik, H. R., Jung, S. C., Baik, K. S. and 
Choi, S. K. 2009. Isolation of bacteria from chunggukjang prepared by rice straw and Identification of protease secreted. J Life Sci 19, 397-402.

15. Peng, Y., Huang, Q., Zhang, R. H. and Zhang, Y. Z. 2003. Purification and characterization of a fibrinolytic enzyme produced by Bacillus amyloliquefaciens DC-4 screened from douche, a traditional Chinese soybean food. Comp Biochem Physiol 134B, 45-52.

16. Sumi, H., Hamada, H., Tsushima, H., Mihara, H. and Muraki, H. 1987. A novel fibrinolytic enzyme (nattokinase) in the vegetable cheese natto; a typical and popular soybean food in the Japanese diet. Experientia 43, 1110-1111.
17. Wei, H., Wei, L., Frenkel, K., Bowen, R. and Barnes, S. 1993. Inhibition of tumor promoter-induced hydrogen peroxide formation in vitro and in vivo by genistein. Nutr Cancer 20, $1-12$.

18. Wei, X., Luo, M., Xu, L., Zhang, Y., Lin, X., Kong, P. and Liu, H. 2011. Production of fibrinolytic enzyme from Bacillus amyloliquefaciens by fermentation of chickpeas, with the evaluation of the anticoagulant and antioxidant properties of chickpeas. J Agric Food Chem 59, 3957-3963.

19. Weisburg, W. G., Barns, S. M., Pelletier, D. A. and Lane, D. J. 1991. 16S ribosomal DNA amplification for phylogenetic study. J Bacteriol 173, 679-703.

\section{초록 : 청국장으로부터 혈전용해 활성이 우수한 균주 분리 및 혈전용해효소정제}

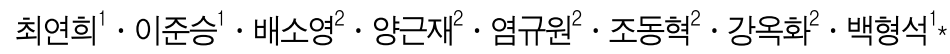

( ${ }^{1}$ 부산대학교 미생물학과, ${ }^{2}$ 부산과학고등학교)

혈전용해효소를 생산하는 균주 분리를 위해서 우선 한국, 일본 등지에서 모은 21 개의 청국장 시료를 준비하였 고 총 268 개의 균주를 분리하였다. 이 중에서 $1 \%$ skim milk가 포함된 nutrient agar 배지에서 protease를 생산하 는 bacteria를 분리하였고, 이 결과로 22개의 균주가 분리되었다. 균주들은 apiweb을 통해 생화학적 특성에 근거 하여 동정하였다. 또한 세균동정을 위해 $16 \mathrm{~S} \mathrm{rRNA}$ 염기서열 분석을 수행하였다. 분리된 대부분의 균주는 Bacillus subtilis와 Bacillus amyloliquefaciens였다. 혈전용해효소의 활성은 fibrin plate 방법에 의해 측정되었고 A2-14, A2-20, C1-05, C1-09, F2-01로 명명된 다섯 균주가 선택되었다. 이중에서 A2-20 균주는 강한 혈전용해 활성 을 보였고 동정결과 Bacillus amyloliquefaciens에 가까웠다. A2-20 균주에 의해 생산되는 혈전용해효소는 균 상등액 을 이용한 gel filtration과 ion exchange chromatography를 거쳐 부분정제 되었다. 부분 정제된 효소의 최적 $\mathrm{pH}$ 는 7.0 이었고, 최적 온도는 $35^{\circ} \mathrm{C}$ 였다. 정제된 단백 질의 분석은 SDS-PAGE와 zymography로 이루어졌다. 이와 더 불어 혈전용해효소의 유전자적 분석도 수행 되었으며 A2-20 균주가 생산하는 혈전용해효소의 부분적인 염기서열 과 유전적 상동성을 보이는 서열을 규명하였다. 